\title{
Congress gives supercollider easy round but worries about cost
}

\section{Washington}

The proposal to build the $\$ 4.4$ billion Superconducting Supercollider (SSC) is facing its first major test since President Reagan gave it his blessing in January. After three days of hearings by the House Committee on Science, Space and Technology beginning on 7 April, it was clear that SSC is respected for its scientific merits but that there are worries about the cost.

And, as a sign of things to come, testimony from various states' spokesmen, ostensibly to demonstrate the breadth of general support for the SSC, quickly turned into an unashamed procession of pitches for particular sites.

The first day of the hearings was mostly devoted to science, with an array of witnesses including Steven Weinberg, Leon Lederman (director of Fermilab), Herwig Schopper (director of CERN), Robert Schrieffer (of the BCS theory of superconductivity) and more. But science was not uppermost in the Committee's mind.

Alvin Trivelpiece, outgoing director of Energy Research at the Department of Energy (DOE), was questioned for almost three hours on the cost of SSC, its effect on other research, the significance of the new superconductors and (clearly most important for some congressmen) the logic of the site selection procedure.

In their opening statements, many committee members alluded to the general benefits of large science projects. The falling quality of science education and the faltering competitiveness of high technology industries were frequently cited as reasons for giving US science a helping hand. But Dan Ritter of Pennsylvania thought the money would be better spent directly on applied research, especially now that high temperature superconductors are causing so much excitement. Reports that the Japanese government will try to build a liquid nitrogen cooled superconducting magnet in two years seemed to him a reason to delay the SSC for a while.

Maury Tigner, director of the SSC Central Design Group, did not believe that high-quality magnets could be made using the new superconductors in less than ten years, and therefore saw not a reason to delay but rather a hope that the SSC might be upgraded to substantially higher energies, perhaps in twenty years. In any case, removing the liquid helium cooling systems would save only about 5 per cent of the construction and running costs over the first decade of operation.

Many of the scientific witnesses agreed with Trivelpiece that the SSC should not go ahead at the expense of 'small science'.
But only James Krumhansl, professor of physics at Cornell University, was openly hostile to the project. After saying that he found the SSC "truly exciting", he argued that cutbacks in other areas were an inevitable side effect. Because annual reviews of science expenditure are mandatory, there is no way that funds can be set aside for one project over a period of years.

The most insistent questions during Trivelpiece's testimony concerned site selection. The official invitation for site proposals was issued on 1 April, with a deadline for submissions of 3 August. This was felt to be too short a preparation period by many congressmen, especially those from states which had followed DOE's advice and not begun a site search in earnest until after presidential approval had been given.

Committee member Tim Valentine of North Carolina complained that the pro-

cedure did not allow his state and many others to match the already wellresearched efforts of big spenders such as Illinois, Texas and California, although his objection was somewhat mitigated the next day when Governor James Martin of North Carolina presented testimony which went from praise of the SSC to a summary site proposal, mentioning the different kinds of rocks in his state, the nature of groundwater distribution as well as the pleasant way of life to be had there.

Spokesmen for Illinois and California, on the other hand, said that anyone with a serious interest in the SSC would have known two years ago that a site invitation was on its way. Illinois has already spent $\$ 4.5$ million on site research, and is proposing to spend $\$ 15$ million more to advance its claim that the SSC should be built near Fermilab, which it would use as an injector.

Trivelpiece and all the SSC supporters hope that site selection can be carried out agreeably. Too much bickering between the states could result in widespread political support for the project collapsing.

David Lindley

\section{Japan takes action to control trade of endangered wildlife}

\section{Tokyo}

JAPAN is at last taking legislative action to control the illegal import of endangered wildlife. But conservationists say the new bill, expected to be submitted to the current session of the Diet, will fail to halt most of Japan's illegal trade.

Japan signed the Washington Convention on International Trade in Endangered Species of Wild Fauna and Flora in

\section{COMPASSIONATE JAPANESE OFFICIAL (ENDANGERED SPECIES)}

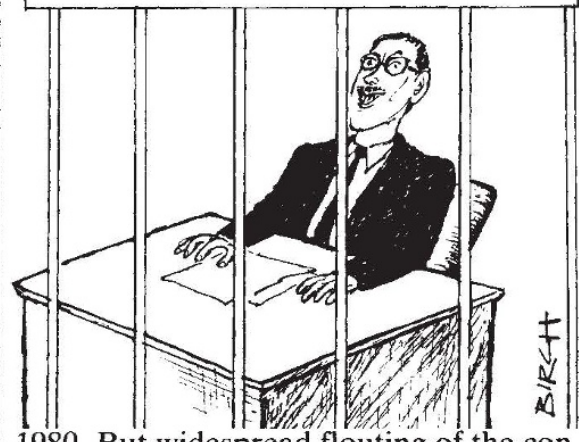

1980. But widespread flouting of the convention prevails because Japan has no domestic legislation to back the convention's provisions.

The new bill bans the import of 492 species of fauna and flora and provides for a maximum fine of $Y 300,000(\$ 2,000)$ or a six-month sentence for violators. The legislation also empowers the authorities to enter pet shops and zoos to make onthe-spot investigations. The bill fails, however, to stipulate the return of illegally imported wildlife to the country of origin.

Tom Milliken, director of TRAFFIC Japan, the trade monitoring area of the World Wildlife Fund, also points out that nearly all the species covered by the new bill are Appendix 1 species, trade in which is totally banned. But by far the greater volume of illegal trade in Japan occurs in Appendix 2 species which are not covered by the new legislation.

Reservation species are also excluded from the new law. On signing the convention, Japan exempted 14 Appendix 1 species - more than any other party to the convention - including six species of whale, three species of monitor lizard, the saltmarsh crocodile and the Himalayan musk deer.

Finance Ministry records show that last year Japan imported $367 \mathrm{~kg}$ of musk, 90 per cent illegally smuggled from China. One kilogram of musk fetches about Y10 million $(\$ 70,000)$ on the Japanese market but requires the slaughter of more than 100 animals. The musk deer has been wiped out in most of India and is found only in a few isolated areas of the Himalayas. The musk is used to make perfumes and a traditional Chinese aphrodisiac.

Under strong pressure from abroad, MITI and the Ministry of Health and WeIfare jointly agreed in February to remove the musk deer from the reservation list... by March 1989.
David Swinbanks 